\title{
Examination of Magnetic Gear using Polar Anisotropic Bonded Magnet
}

\author{
M. Fukuoka, K. Nakamura, and O. Ichinokura \\ Graduate School of Engineering, Tohoku University, 6-6-05 Aoba Aramaki Aoba-ku, Sendai 980-8579, Japan
}

\begin{abstract}
Magnetic gears can transmit torque without mechanical contact. They therefore have low vibration and acoustic noise, and are low maintenance in comparison with conventional mechanical gears. Various types of magnetic gears have been introduced. A planetary type magnetic gear has attracted interest recently because of its higher transmission torque compared to other types, and it is expected to be put into practical use. However, it is necessary to reduce the eddy current loss caused by harmonic fluxes in the air gap. This paper presents a magnetic gear using polar anisotropic Nd-Fe-B bonded magnets in which the eddy current is rarely induced.
\end{abstract}

Key words: magnetic gear, polar anisotropic magnet, bonded magnet, eddy current loss

\section{極異方性ボンド磁石を用いた磁気ギアに関する検討}

福岡道成・中村健二・倉理

東北大学 大学院工学研究科, 仙台市青葉区荒巻字青葉 6-6-05（ 980-8579）

\section{1.はじめに}

地球温暖化の原因となる大気污染物質の削減，ならびに省エネ ルギ一対策のため, 風力, 水力, 波力, 地熱, バイオマスなどの 再生可能エネルギーの活用が望まれている. ここで一般に，これ らの電源の動力源と，接続される発電機の回転数は異なるため, ギアを用いて所望の回転数まで増減速する必要がある. そのため, ギアには小型，高出力，高効率，低保守，低騒音であることが強 く望まれる. しかしながら，現在広く一般に用いられている機械 式ギアは接点を有するため, 接触部からの騒音や潤滑油系統が必 要であること, また部品点数の多さによる保守管理の複雑化とい った問題が指摘される. これに対して, 磁気ギアは非接触で動力 を伝達寸ることができるため, 振動・騒音が小さく，また部品の 摩耗が無いことから，信頼性・保守性の向上が期待される.

これまで様々な種類の磁気ギアが提案されているが1) 3), それら

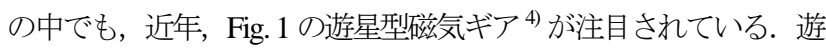
星型磁気ギアは，同心円状に配置された内外の永久磁石回転子と， その間に挟まれたポールピースと呼ばれる固定子で構成されてお り, このポールピースによって, 磁石磁束を変調することでギア として動作する ${ }^{5)}$. ここで, 他の種類の磁気ギアは入力側と出力側 の回転子のある一部分のみを使用してトルクを伝達しているのに 対し，遊星型磁気ギアは，内外の回転子表面に張り付けられたす ベての磁石がトルクの伝達に寄与するため, 他の磁気ギアに対し

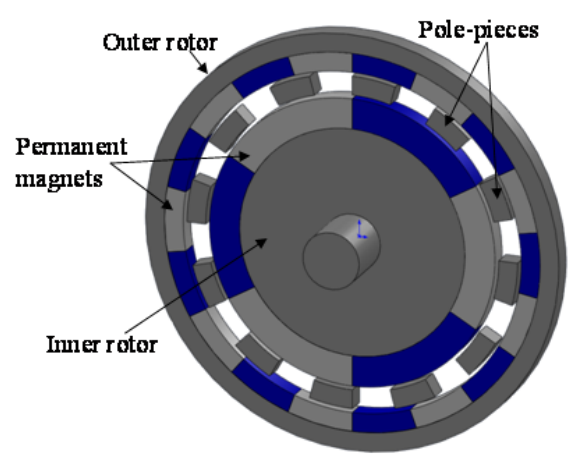

Fig. 1 Basic structure of planetary type magnetic gear $5), 6)$.
てトルク密度が高い 5),6)。しかしながら一方で，磁石磁束の変調で 生じる非同期の高調波磁束によって，回転子磁石には渦電流損が 生じることが指摘されており ${ }^{7}$, 今後の実用化のためには, 磁石渦 電流損の低減が必要不可欠である.

そこで本稿では，性質上，渦電流がほとんじ生じないボンド磁 石に着目した. ただし，ボンド磁石の磁気特性は，一般的な焼結 磁石に対して劣ることが知られており, 単純な置き換えでは所望 のトルクを得ることはできない，そこで極異方性着磁に着目し， 従来のラジアル異方性着磁の磁石と特性の比較を行うとともに, 極異方性着磁されたボンド磁石を適用した磁気ギアの特性につい て, 有限要素法 (FEM) を用いて検討を行ったので報告する.

\section{2. 極異方性ボンド磁石の特性}

\section{1 焼結磁石とボンド磁石の磁気特性の比較}

Fig. 2 に, 広く一般に用いられている希土類焼結磁石と, 本稿で の検討に用いる希土類ボンド磁石の磁気特性を示す。材質は Nd-Fe-B であり, 焼結磁石およびボンド磁石の残留磁束密度 $B_{r}$ は それぞれ1.25T, 0.8Tである. また, 保磁力 $H_{c}$ はそれぞれ $975 \mathrm{kA} / \mathrm{m}$, $500 \mathrm{kA} / \mathrm{m}$ である. この図を見ると, ボンド磁石の磁気特性は焼結 磁石の約 6 割程度であることがわかる. したがって, 同形状・同 寸法の磁気ギアの磁石を単純にボンド磁石に置き換えた場合, 仮 に磁石渦電流損をゼロにできたとしても, 伝達トルクは小さくな ることが容易に想像される.

そこで本稿では，Fig. 3(a)に示寸極異方性着磁に着目する. 同図 (b)に示す一般的なラジアル異方性着磁に対して, 極異方性着磁で

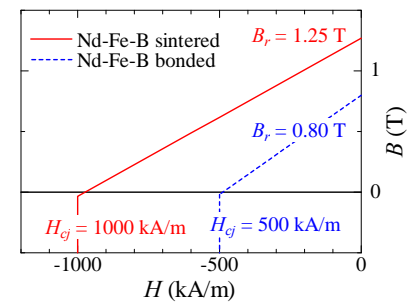

Fig. 2 Demagnetization curves of $\mathrm{Nd}-\mathrm{Fe}-\mathrm{B}$ sintered and bonded magnets. 
は磁石磁束が一方の面に集中寸るため，磁石磁束が増加，回転子 ヨークが不要などの特長を有する．以下，簡単な磁気回路を用い

て, ラジアル異方性磁石と極異方性磁石の特性の比較を行う.

\section{2 ラジアル異方性磁石と極異方性磁石の特性比較}

Fig. 4 に，考察に用いた解析モデルを示寸. 永久磁石の材質は Nd-Fe-B であり, 残留磁束密度 $B_{r}$, 保磁力 $H_{c}$ はそれぞれ, $0.8 \mathrm{~T}$, $500 \mathrm{kA} / \mathrm{m}$ である. 磁石 1 極対の $x$ 軸方向の長さは $100 \mathrm{~mm}$ であり, 永久磁石と鉄心の間に設けたギャップの長さは $10 \mathrm{~mm}$ である. 鉄 心の透磁率は無限大とし，積厚方向への漏孔磁束は無視する。ま た，同図(a)の極異方性磁石の解析モデルでは，磁束は磁石内で円 弧状に流れると仮定し, バックヨークは無視する.

Fig. 5 に，上述の仮定に基づき導出した磁気回路モデルを示す. 同図(a)において，永久磁石の内部磁気抵抗 $R_{m x}$ および $R_{m y}$ は，次式 で与えられる.

$$
\begin{aligned}
& R_{m x}=l_{x} /\left(2 \mu_{r} \mu_{0} l_{y} D\right) \\
& R_{m y}=l_{y} /\left(2 \mu_{r} \mu_{0} l_{x} D\right)
\end{aligned}
$$

ここで， $l_{x}$ および $l_{y}$ は，それぞれ磁石の $x$ 軸および $y$ 軸方向の長さ であり， $D$ は積み厚である. また， $\mu_{r}$ は永久磁石のリコイル比透 磁率であり， $\mu_{0}$ は真空の透磁率である.

次いで, ギャップの磁気抵抗 $R_{\text {air }}$ は, 次式で与えられる.

$$
R_{\text {air }}=g /\left(\mu_{0} l_{x} D\right)
$$

ここで, $g$ はギャップ長である.

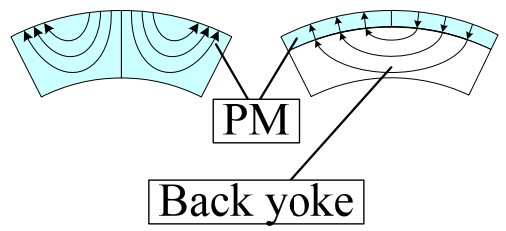

(a) Polar magnet (b) Radial magnet

Fig. 3 Lines of magnetic force of magnets.

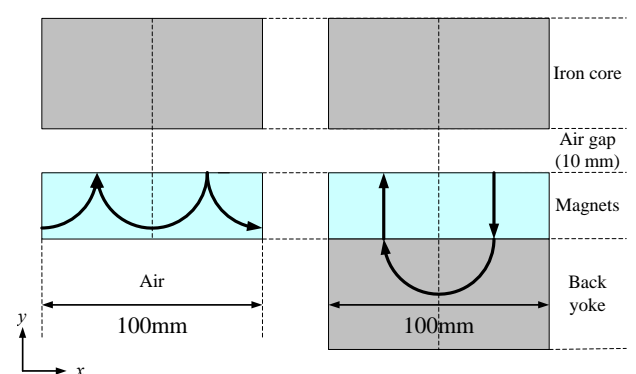

(a) Polar magnet $\quad$ (b) Radial magnet

Fig. 4 Analytical models of polar and radial magnets.

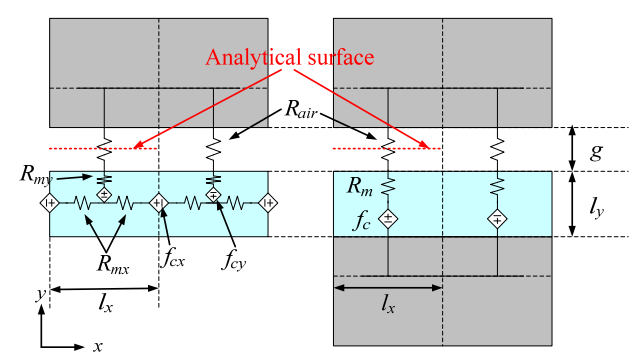

(a) Polar magnet $\quad$ (b) Radial magnet

Fig. 5 Magnetic circuit models of polar and radial magnets.

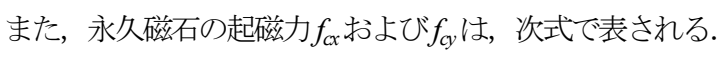

$$
\begin{aligned}
& f_{c x}=H_{c} l_{x} / 2 \\
& f_{c y}=H_{c} l_{y} / 2
\end{aligned}
$$

ここで, $H_{c}$ は磁石の保磁力である.

一方, Fig. 5(b)のラジアル異方性磁石の磁気回路モデルにおいて, 永久磁石の内部磁気抵抗 $R_{m}$ は, 次式で与えられる.

$$
R_{m}=l_{y} /\left(\mu_{r} \mu_{0} l_{x} D\right)
$$

また, ギャップの磁気抵抗 $R_{\text {air }}$ は, (3)式で与えられる.

次いで，永久磁石の起磁力 $f_{c}$ は，次式で表される.

$$
f_{c}=H_{c} l_{y}
$$

以上のようにして導出した磁気回路モデルを用いて, 磁石の $y$ 軸方向の長さ $l_{y}$ に対するギャップ磁束密度を計算し, 極異方性磁 石とラジアル異方性磁石の特性を比較する.

Fig. 6 に, 磁石の $y$ 軸方向の長さ $l_{y}$ に対するギャップ磁束密度の 算定結果を示寸.この図を見ると, ラジアル異方性磁石の場合, $l_{y}$ の増大に伴い, ギャップ磁束密度はある一定值に漸近することが わかる. これは(6)式と(7)式から明らかなように, 起磁力 $f_{c}$ と内部 磁気抵抗 $R_{m}$ がともに, 磁石の長さ $l_{y}$ に比例するためである.

一方, 極異方性磁石の場合は $l_{y}$ が増大しても, ギャップ磁束密 度はある一定值に近づくことはなく, 徐々に上昇し続けることが

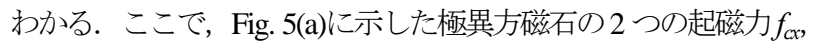
$f_{c y}$ について, 各々の起磁力に由来する磁束を求めた. Fig. 7 に, 起 磁力 $f_{c x}$ および $f_{c y}$ にそれぞれ由来するギャップ磁束密度の算定結果 を示す. このうち, 図中の $f_{c x}$ に由来するギャップ磁束密度を見る と， $l_{y}$ に対して単調に増加し続けていることがわかる。これは, (4) 式の $f_{c x}$ は $l_{y}$ に対して一定であるのに対し, (1)式の内部磁気抵抗 $R_{m x}$ は $l_{y}$ に反比例するためである．以上のことから，極異方性磁石は 磁石長を長くすることで，ラジアル異方性磁石の特性を上回るこ とが了解される.

\section{3. 極異方性ボンド磁石を用いた磁気ギアの特性}

\section{1 トルク特性}

前章の考察により，極異方性磁石を用いることで，一般的なラ ジアル異方性磁石に対して, ギャップ磁束密度が向上することを

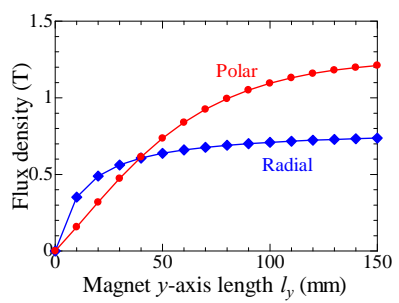

Fig. 6 Gap flux density calculated by magnetic circuit.

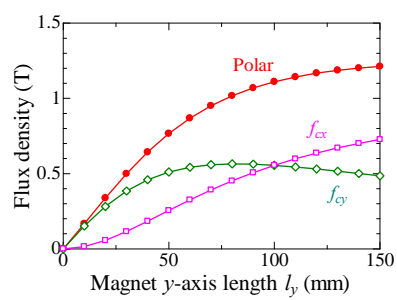

Fig. 7 Division of magnetomotive force of polar anisotropic magnet. 
示した. したがって，従来のラジアル異方性焼結磁石を採用した 磁気ギアに対して，極異方性ボンド磁石で置き換えることで，卜 ルクを保ちつつ，損失の低減が期待される．本節では，従来のラ ジアル異方性焼結磁石と, 極異方性ボンド磁石を用いた磁気ギア の伝達トルクと損失について比較を行う。なお，磁気ギアの特性 算定には，汎用の有限要素法（FEM）プログラムである JMAG-Studio を用いた.

Fig. 8 に，比較対象としたラジアル異方性焼結磁石を用いた磁気 ギアの諸元を示寸.内外の回転子の極詨数は，それぞれ 7 と 17 で あり，その間に配置されたポールピースの極数は 24 である. 永久 磁石の材料は Nd-Fe-B の焼結磁石であり，ポールピースの材質は 6.5\%Si 鋼板, 両回転子のバックヨークの材質は, 無方向性ケイ素 鋼板である. 同図の磁気ギアのギア比は，内側（高速側）と外側 (低速側) の回転子の極対数の比で決まる ${ }^{5}$. すなわち, 1:2.43で ある. 本磁気ギアにおいて, 特性を決める重要なパラメータであ る永久磁石ならびにポールピースの寸法は, 最適化されている7).

Fig. 9 に, 極異方性ボンド磁石を用いた磁気ギアの諸元を示す. Fig. 8 の磁気ギアと比較するため, 体格, 極対数は同一とした. 本 磁気ギアは, Fig. 8 に示した磁気ギアの回転子の永久磁石とバック ヨークを，極異方性ボンド磁石で置き換えている，なお，磁石支 持のため, 両回転子のバックヨークには非磁性金属を用いる.

Fig. 10 に, 極異方性ボンド磁石およびラジアル異方性焼結磁石 を用いた，磁気ギアの伝達トルク最大時の波形を示寸．これらの 図を見ると，極異方性ボンド磁石を用いた磁気ギアは，ラジアル 異方性焼結磁石を用いた磁気ギアと比較して, 伝達トルクが約 13\%向上していることがわかる. これは前章で考察したように, 極異方性磁石は, ラジアル異方性磁石と比べて, 磁石磁束が一方 の面に集中し, ギャッブ磁束密度が高くなるためであると考えら れる.

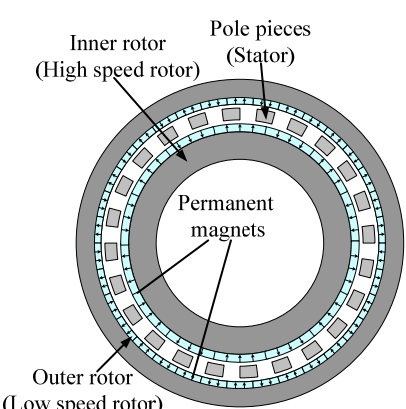

\begin{tabular}{ll}
\hline Magnetic gear & \\
\hline Inner magnet pole-pair : & 7 \\
Outer magnet pole-pair : & 17 \\
Pole-pieces : & 24 \\
Gear ratio : & $1: 2.4286$ \\
Diameter of outer rotor : & $1300 \mathrm{~mm}$ \\
Stack length : & $1000 \mathrm{~mm}$ \\
Core material : & $35 \mathrm{~A} 300$ \\
Pole pieces material : & $6.5 \% \mathrm{Si}$ steel \\
\hline Permanent magnet \\
\hline Material : \\
Residual magnetic \\
$\quad$ Nd-Fe-B Sintered \\
Coercive fonsity : & $1.25 \mathrm{~T}$ \\
\hline
\end{tabular}

(Low speed rotor) Coercive force : $975 \mathrm{kA} / \mathrm{r}$

Fig. 8 Structure and specifications of magnetic gear using radial anisotropic $\mathrm{Nd}-\mathrm{Fe}-\mathrm{B}$ sintered magnets.

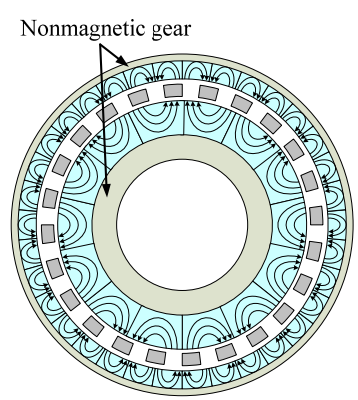

\begin{tabular}{ll}
\hline Magnetic gear & \\
\hline Inner magnet pole-pair : & 7 \\
Outer magnet pole-pair : & 17 \\
Pole-pieces : & 24 \\
Gear ratio : & $1: 2.4286$ \\
Diameter of outer rotor : & $1300 \mathrm{~mm}$ \\
Stack length : & $1000 \mathrm{~mm}$ \\
Pole pieces material : & $6.5 \% \mathrm{Si}$ steel \\
\hline Permanent magnet \\
\hline Material : \\
Residual magnetic & Nd-Fe-B bonded \\
Clux density : & $0.80 \mathrm{~T}$ \\
Coercive force : & $500 \mathrm{kA} / \mathrm{m}$ \\
\hline
\end{tabular}

Fig. 9 Structure and specifications of magnetic gear using polar anisotropic $\mathrm{Nd}-\mathrm{Fe}-\mathrm{B}$ bonded magnets.

\section{2 出カ・損失および効率の算定}

前節の検討により, 極異方性ボンド磁石を用いた磁気ギアは, 従来のラジアル異方性焼結磁石を用いた磁気ギアと同等以上の卜 ルクが得られることが示された．次いで，本節では永久磁石およ び鉄心で生じる損失の解析を行う.

Fig. 11 に，本検討で考慮した磁気ギアの損失を示す，同図(a)の 極異方性ボンド磁石を用いた磁気ギアでは, 導電体である非磁性 ヨークの渦電流損と, ポールピースの鉄損を考慮した. なお, ボ ンド磁石の導電率は，焼結磁石と比較して，無視できるほど小さ いため, ボンド磁石の渦電流損は無視した. 一方, 同図(b)のラジ アル異方性焼結磁石を用いた磁気ギアでは, 磁石の渦電流損と, 回転子ヨークおよびポールピースの鉄損を考慮した.

本稿において, 磁気ギアの効率は, 次式を用いて算出する.

$$
\eta=P_{\text {out }} /\left(P_{\text {out }}+W_{\text {eddy }}+W_{\text {iron }}\right)
$$

ここで, $W_{i v n}$ は鉄心の鉄損, $W_{\text {eddy }}$ は永久磁石および非磁生ヨーク の渦電流損であり， $P_{\text {out }}$ は磁気ギアの機械出力である. 以下，それ ぞれの損失と機械出力の算定手法について述べる.

まず 2 次元 FEMによる鉄損の算定について述べる. 一般に, 磁 束密度波形が正弦波である場合, 鉄心の鉄損 $W_{i v n}$ は, 次のスタイ ンメッツの実験式で与えられる.

$$
W_{i r o n}=A_{h} f B_{m}{ }^{2}+A_{e} f^{2} B_{m}{ }^{2}
$$

式中の $f$ は周波数, $B_{m}$ は最大磁束密度, $A_{h}$ および $A_{e}$ は, ヒステリ シス損係数および渦電流損係数である. なお, 実際の磁束波形は 高調波を含んだ歪み波となるため, 2 次元 FEM で求めた磁束密度 波形をフーリエ解析し，(9)式より各次高調波成分の鉄損を求め, それらの和を全体の鉄損とする.

次いで, 3 次元 FEMによる永久磁石および非磁生ヨークの渦電 流損算定について述べる. 汎用の FEM プログラムである JMAG-Studio において, 渦電流を考慮した電磁界解析の基礎方程 式は, 次式で与えられる。

$$
\operatorname{rot}(v \operatorname{rot} \mathbf{A})=J_{0}-\sigma(\partial \mathbf{A} / \partial t)+\operatorname{grad} \phi
$$

上式中の $\mathbf{A}$ およびфは，それぞれベクトルポテンシャルとスカラ

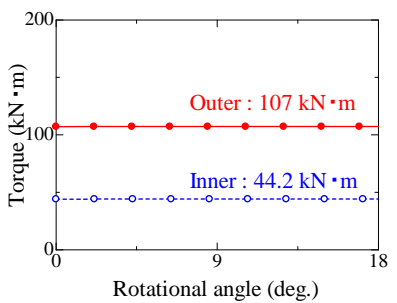

(a) Polar magnet

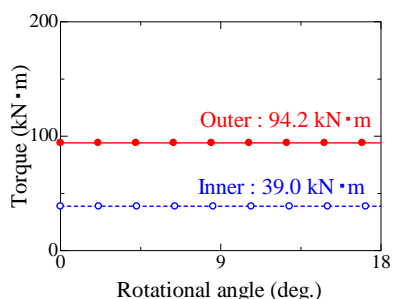

(b) Radial magnet
Fig. 10 Torque waveforms calculated by FEM.

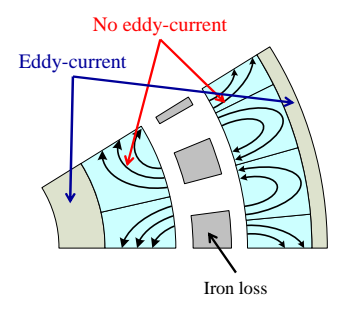

(a) Polar magnet

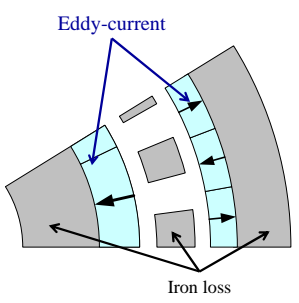

(b) Radial magnet
Fig. 11 Illustrations of magnets considering magnetic gear loss. 
ポテンシャルである. $v$ は磁気抵抗率， $J_{0}$ は強制電流密度， $\sigma$ は導 電率である.

ここで, Fig. 8 およびFig. 9 の磁気ギアの積み厚は $1000 \mathrm{~mm}$ であ るが，厚さ $1000 \mathrm{~mm}$ のボンド磁石およひ焼結磁石を作ることは不 可能であるため, 実際に製作可能な厚み $5 \mathrm{~mm}$ の磁石を, 積夕厚方 向に 200 枚積み重ねると仮定し，解析を行った，なお，これらの 積み重ねられた磁石同士は，電気的に絶縁されており，また周方 向に隣接する磁石同士も, 電気的に絶縁されていると仮定した.

非磁性ヨークおよひ磁石に流れる渦電流は表皮効果の影響を受 ける，表皮厚さ $d$ は，次式で表される.

$$
d=1 / \sqrt{\sigma f \mu \pi}
$$

ここで，定格回転時に回転子の永久磁石に流れる磁束の基本周波 数は，内側で $2.91 \mathrm{kHz}$ ，外側で $1.2 \mathrm{kHz}$ である. 極異方性ボンド磁 石を用いた磁気ギアでは，非磁性ヨークの導電率 $\sigma=8.40 \times 10^{5} \mathrm{~S} / \mathrm{m}$ と，透磁率 $\mu=1.0 \times 4 \pi \times 10^{-7} \mathrm{H} / \mathrm{m}$ を用いて，それぞれの表皮厚さは 内側で約 $11 \mathrm{~mm}$, 外側で約 $16 \mathrm{~mm}$ と求まる. したがって, Fig. 12(a) に示すように，非磁性ヨークとボンド磁石が接する面から表皮深 さ以上の領域を，十分に細かいメッシュで分割し，表皮効果を考 慮できるようにした.

一方，ラジアル異方性焼結磁石を用いた磁気ギアでは，焼結磁 石の導電率 $\sigma=6.67 \times 10^{5} \mathrm{~S} / \mathrm{m}$ と透磁率 $\mu=1.037 \times 4 \pi \times 10^{-7} \mathrm{H} / \mathrm{m}$ を用 いて，それぞれの表皮厚さは内側で約 $12 \mathrm{~mm}$, 外側で約 $18 \mathrm{~mm}$ と 求まる. したがって，同様に同図(b)に示すように，磁石表面から 表皮深さ以上の領域を細かくメッシュ分割した.

最後に，磁気ギアの機械出力の算定について述べる．磁気ギア の機械出力 $P_{\text {out }}$ は, 上述の渦電流を考慮した 3 次元 FEM 解析によ り得られた出力側のトルク $\tau(\mathrm{N} \cdot \mathrm{m})$ と回転数 $n(\mathrm{r} / \mathrm{min})$ を用いて, 次 式で与えられる.

$$
P_{\text {out }}=2 \pi n \tau / 60
$$

本稿において, 出力側の定格回転数は $3,000 \mathrm{r} / \mathrm{min}$ である.

以上のようにして算定した両磁気ギアの機械出力，損失および 効率を Table 1 に示す.この表を見ると，極異方性ボンド磁石を用 いることで，磁気ギアで生じる損失を約 $80 \%$ 低減することが可能
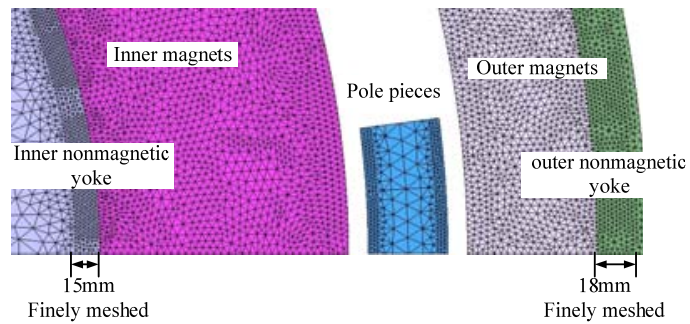

(a) Polar magnet

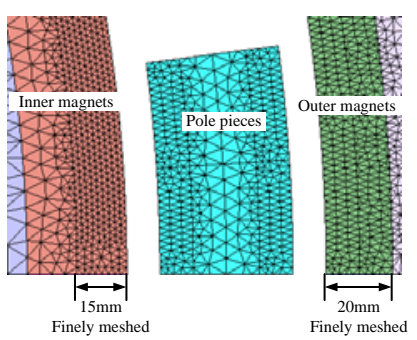

(b) Radial magnet

Fig. 12 FEM model around gap considering skin effect.
Table 1 Comparison of losses and efficiency of magnetic gears.

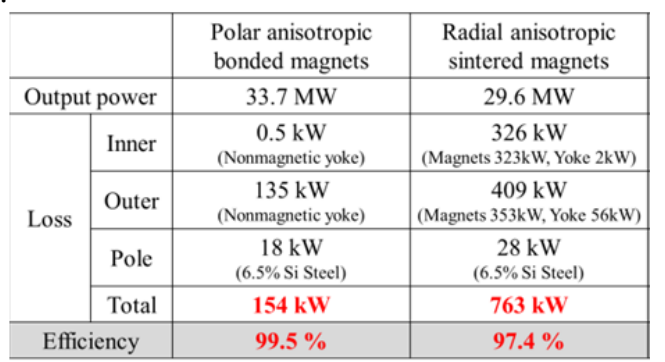

であることがわかる．また，磁気ギアの効率は，従来のラジアル 異方性焼結磁石を用いた磁気ギアで 97.4\%, 極異方性ボンド磁石を 用いた磁気ギアで 99.5\%となった. 現在広く一般に用いられている 機械式ギアの効率は，高いもので 95\%～98\%であるため，極異方 性ボンド磁石を採用することで, 機械式ギアよりも高い伝達効率 が得られる可能性がある.

\section{4. まとめ}

以上，本稿では極異方性ボンド磁石を用いた磁気ギアの特性 について, 有限要素法（FEM）を用いて検討を行った。

まず初めに，極異方性着磁されたボンド磁石の特性について， 簡単な磁気回路を用いて考察を行った. その結果, 極異方性磁石 は磁石長を長くすることで, 従来のラジアル異方性磁石の特性を 上回ることが明らかになった。

次いで，極異方性ボンド磁石を適用した磁気ギアのトルク特性 について評価を行った. その結果, ボンド磁石の磁気特性は焼結 磁石に劣るが，極異方性着磁を採用寸ることで，同等以上のトル クが得られることが明らかになった。

最後に, 磁気ギアの損失と効率について検討を行った. 極異方 性ボンド磁石を採用することで，従来の焼結磁石を用いた磁気ギ アに対して，損失が約 80\%低减され，効率が 99.5\%に達すること が示された.

今後は, 極異方性ボンド磁石を用いた磁気ギアを試作し, 実機試験を行うことで，本磁気ギアの有用性を実証する予 定である，なお，本研究の一部は，科学研究費補助金若手 研究 A（22686028）の交付を得て行った.

\section{References}

1) D. E. Hesmondhalgh and D. Tipping: "A multielement magnetic gear", IEE Proc. Elect. Power Appl., 127, 129 (1980).

2) K. Tsurumoto and S. Kikushi: "A new magnetic gear using permanent magnet”, IEEE Trans. Magn., 23, 3622 (1987).

3) K. Ikuta, S. Makita, and S. Arimoto: "Non-contact magnetic gear for micro transmission mechanism”, Proc. IEEE Conf. on Micro electromechanical systems (MEMS '91), p.125 (1991).

4) T. B. Martin, Jr.: “Magnetic transmission,” U.S. Patent 3,378,710, Apr. 16 (1968).

5) K. Atallah and D. Howe : "A Novel High-Performance Magnetic Gear”, IEEE Trans. Magn., 37, 2844 (2001).

6) K. Atallah, S. D. Calverley, and D. Howe: "Design, analysis and realization of a high-performance magnetic gear", IEE Proc. Elect. Power Appl., 151, 135 (2004).

7) Tetsuya Ikeda, Kenji Nakamura, Osamu Ichinokura : "Consideration of Rotor Structure in Permanent-Magnet Magnetic Gears", J. Magn. Soc. Jpn., 33, 130 (2009).

2011年10月21日受理，2011年12月13日採録 